\title{
The Updated International Veterinary Anatomical and Embryological Nomenclatures
}

\author{
Gheorghe M. Constantinescu* and Ileana A. Constantinescu \\ Department of Biomedical Sciences, College of Veterinary Medicine, University of Missouri-Columbia
}

*Corresponding author: Gheorghe M. Constantinescu, DVM, PhD, mult. Drhc, Professor of Veterinary Anatomy and Medical Illustrator, University of Missouri-Columbia, 1600 E Rollins, Columbia, Missouri 65211-5120, USA, Fax: (573)884-6890, Tel: (573)882-7249, E-mail: constantinescug@missouri.edu

Citation: Gheorghe M. Constantinescu, Ileana A. Constantinescu (2013) The Updated International Veterinary Anatomical and Embryological Nomenclatures. J Vet Sci Anim Husb 1(2): e201. doi: 10.15744/2348-9790.1.e201

Received Date: September 17, 2013 Accepted Date: September 30, 2013 Published Date: October 07, 2013

The international nomenclature of the anatomical, histological and embryological terms is known as Nomina Anatomica Veterinaria (N.A.V.), Nomina Histologica Veterinaria (N.H.V.) and Nomina Embryologica Veterinaria (N.E.V.).

This is the tripod of terms for the morphological sciences in our profession, a dictionary of terms used by all specialists in the basic and in the clinical sciences.

The year 2005 brought to the international veterinary community the fifth edition (electronic version, website of the World Association of Veterinary Anatomists - W.A.V.A.) of the Nomina Anatomica Veterinaria[1], revised in 2012[2], and one year later, in 2006 the second edition of the Nomina Embryologica Veterinaria (electronic version website of W.A.V.A.)[3].

The previous editions of the N.A.V. have been published on paper in 1968, 1973, 1983 and 1994. The first edition of the N.E.V. [4] has been published on paper in 1994, together with the 4 th edition of the N.A.V. and the revised second edition of the N.H.V.

The updated N.A.V. consists of 6,545 Latin terms and the updated N.E.V. consists of 2,986 Latin terms.

In 1992 was published the first edition of the Illustrated Veterinary Anatomical Nomenclature - I.V.A.N. - (O. Schaller Editor, Enke Verlag) and in 2012 the third edition (G. M. Constantinescu and O. Schaller Editors) [5]. The illustrated version of the N.A.V. follows step by step and chapter by chapter the anatomical terms of the N.A.V. However, G. M. Constantinescu updated the text, added many other important general terms (69) and gave short explanations to all 453 general terms. Also, he introduced a List with Eponyms for the Central Nervous System with the pages where those terms can be found. The List with Eponyms was added for the benefit of neurologists, neuroanatomists, neurosurgeons and those especially interested in the Central Nervous System.

Updating the text from the previous editions was followed by updating the labels of the figures. In addition, some figures have been replaced by new and original drawings made by G. M. Constantinescu. The illustrations are all original and drawn by the contributors or illustrators under the contributor's directions. The revision included changes in the text, comments and footnotes, with the accent on the anatomical terms with clinical relevance, especially those terms used in clinics as landmarks and approaches for Internal Medicine and Surgery, and in general for physical examination.

All ontogenetic terms have been removed because they are included in the N.E.V. The rabbit (Oryctolagus cuniculus) has been introduced for the first time in the $5^{\text {th }}$ edition of the N.A.V. in Osteologia, Arthrologia and Systema lymphaticum and it appears also in the I. V. A. N. $3^{\text {rd }}$ edition.

Examples of important changes that Professor Constantinescu asked for and have been approved by the International Committee on Veterinary Gross Anatomical Nomenclature ( I.C.V.G.A.N.) and W.A.V.A. are those which replaced Greek terms by Latin terms, replacement of obsolete terms by new and logical terms, introduction of new and self-explanatory terms, etc.

The Greek term Peronē (Peroneus - corresponding Latin term) has been replaced by Fibula, a genuine Latin term. However, the muscles have been called in all four preceding editions as "peroneus - M. peroneus [peronaeus, fibularis] longus, tertius, or brevis", term which has been replaced in the 5 th edition by "fibularis". Similar situations have been taken care of throughout the book.

There is a M. rhomboideus atlantis in the pig.

The Mm. multifidi have been listed as "laterales", "mediales" and "profundi".

The Lig. inguinale has been replaced by Arcus inguinalis (a ligament cannot be part of a muscle).

The Fascia brachii, the Fascia antebrachii and the Fascia lata 
have been listed as "Lamina superficialis" and "Lamina profunda", whereas the Fascia cruris has been listed as "Lamina superficialis", "Lamina profunda" and "Lamina propria".

The M. levator ani consists in Ungulates of three fascicles: "coccygeal", "anal" and "perineal", not mentioned in the N.A.V., but illustrated and not labeled in the previous editions of I.V.A.N.

The resystematization followed by correct labeling of the figures of several arteries, veins, lymphnodes and peripheral nerves has been one of the most important improvement of the I.V.A.N.

Even though anatomical terms including for example "Tapetum lucidum, "Lamina basalis choroideae" "Pupilla" were omitted from the $5^{\text {th }}$ edition of the N.A.V., they have been introduced in the $3^{\text {rd }}$ edition of I.V.A.N. associated with a note. However, such terms have been listed in the $4^{\text {th }}$ edition of the N.A.V.

Even though it has been demonstrated that the "Retina" is a unique structure after birth, and the I.C.V.G.A.N. has been noticed several times about this fact, the terms "Pars optica retinae" and "Pars ceca retinae" persist in the $5^{\text {th }}$ edition of the N.A.V. However, in the $3^{\text {rd }}$ edition of I.V.A.N. there is a note about this controversial issue. Pars optica retinae and Pars ceca retinae are embryological terms.

Two examples of international anatomical nomenclature from the $4^{\text {th }}$ edition of the N.A.V. can be found in Constantinescu GM, Clinical Anatomy for Small Animal Practitioners 2002 [6], and in Constantinescu GM, Constantinescu IA, Clinical Dissection Guide for LARGE Animals, Horse and Large Ruminants $2^{\text {nd }}$ edition, 2004 [7]. G. M. Constantinescu updated the international anatomical nomenclature of the chapter Myologia in the $5^{\text {th }}$ edition of the N.A.V. [8] and coauthored the nomenclature of the chapter Systema Nervosum Periphericum [9] . In addition to the corresponding texts, he also illustrated the chapters Systema Nervosum Centrale [10] , Periphericum [11] and Autonomicum[12] from the $3^{\text {rd }}$ edition of I.V.A.N.

Prof. G. M. Constantinescu is a member of the International Committee on Veterinary Gross Anatomical Nomenclature, Chairman of the Subcommittee of Myologia, co-editor of the $5^{\text {th }}$ edition of the N.A.V. and Editor of the $3^{\text {rd }}$ edition of the Illustrated Veterinary Anatomical Nomenclature, 2012.

The embryological terminology has been improved by introducing new terms (26), currently 2,986 and replacing obsolete terms by new terms. The following are some examples of newly introduced terms, with the corresponding explanations.

Compactio is a newly introduced term to name the event in early cleavage-stage mammalian embryos, during which blastomeres become tightly joined, maximizing their contact with one another and forming a compact ball of cells. The process of compaction is readily visible in in vitro cultured Morulae and Blastulae and is an important criterion for assessing preimplantation embryos.

Processus neuralis is a novel term referring to the phylogenetic origin of Arcus vertebrae.
Osteocranium is a newly introduced term, commonly used in textbooks of veterinary embryology.

Lamina epiphysialis has been replaced by Cartilago physialis.

"Plica genitalis" replaces the former term Septum urogenitale which was often confused with Plica urogenitalis or Septujm urorectale. It denotes the peritoneal fold which separates Excavatio rectogenitalis from Excavatio vesicogenitalis in postnatal life and contains the Ductus deferens in the male.

Neurectoderma opticum is a novel term to situate the origin of the retina.

Stratum nervosum (retinae) belonging to the Pars optica retinae is a newly introduced term adopted from the N.A.V. and N.H.V. It denotes the retinal portion that develops from the inner layer of the optic cup and differentiates into a multilayered arrangement of nerve cells. This is true during the developmental life. After birth, however, the retina is a unique structure which ends at the ora serrata and continues anteriorly with the nonpigmented epithelium of the ciliary body. After birth there is no Pars ceca retinae [6].

Epithelium nonpigmentosum (retinae) replaces the former term Epithelium ciliare.

Epithelium pigmentosum (retinae) replaces the former term Epithelium iridicum.

Ectoderma opticum is a novel term introduced to situate the origin of the anterior corneal epithelium.

Junctio media thoraco-epigastrica is a novel term replacing the former Junctio media thoraco-gastrica, indicating the body wall regions that are fused.

Craniosynostosis is the term replacing Craniosynotosis from the first edition, because it is far more descriptive and more frequently used.

Assist. Prof. Ileana A. Constantinescu is a member of the International Committee on Veterinary Embryological Nomenclature.

\section{References}

1. International Committee on Veterinary Gross Anatomical Nomenclature (1994) Nomina Anatomica Veterinaria (4th edn) and Nomina Embryologica Veterinaria .Zürich and Ithaca, New York.

2. International Committee on Veterinary Gross Anatomical Nomenclature (2005) Nomina Anatomica Veterinaria (5th edn), World Association of Veterinary Anatomists (W.A.V.A.)

3. N.E.V.(2006) Nomina Embryologica Veterinaria (2nd edn), World Association of Veterinary Anatomists(W.A.V.A.)

4. International Committees on Veterinary Gross Anatomical Nomenclature(1994) Nomina Anatomica Veterinaria (4th edn), the revised (2nd edn) of Nomina Histologica Veterinaria and Nomina Embryologica Veterinaria, Zürich and Ithaca, New York

5. Constantinescu GM, Schaller O.(2012) Illustrated Veterinary Anatomical Nomenclature, Enke

6. Constantinescu GM, (2002) Clinical Anatomy for Small Animal Practitioners, IS Press: Wiley, New York, USA.

7. Constantinescu GM, Constantinescu IA (2004): Clinical Dissection Guide for Large Animals, Horse and Large Ruminants, (2nd edn) Wiley, New York, USA.

8. Waibl H, Gasse H, Constantinescu GM, Hashimoto Y, Simoens P (2005) Myologia. In Nomina Anatomica Veterinaria (5th edn) 
9. Waibl H, Gasse H, Constantinescu GM, Hashimoto Y, Simoens P (2005) Systema Nervosum Periphericum: Nomina Anatomica Veterinaria (5th edn). 10. Constantinescu GM (2012) Systema Nervosum Centrale: Illustrated Veterinary Anatomical Nomenclature, Enke.
11. Constantinescu GM (2012 ) Systema Nervosum Periphericum: Illustrated Veterinary Anatomical Nomenclature, Enke.

12. Constantinescu GM (2012) Systema Nervosum Autonomicum: Illustrated Veterinary Anatomical Nomenclature, Enke.

\footnotetext{
Submit your next manuscript to Annex Publishers and benefit from:

> Easy online submission process

> Rapid peer review process

> Online article availability soon after acceptance for Publication

> Open access: articles available free online

> More accessibility of the articles to the readers/researchers within the field

> Better discount on subsequent article submission

Submit your manuscript at

http://www.annexpublishers.com/paper-submission.php
} 